\title{
Kalibrasi Persamaan Thornthwaite Dan Evaporasi Panci Untuk Memprediksi Evapotranspirasi Potensial Pada Daerah Dengan Data Cuaca Terbatas
}

\section{Calibration of Thornthwaite and Pan Evaporation equations for Estimating Potential Evapotranspiration from areas under limited weather data condition}

\author{
Humairo Saidah*, Heri Sulistyono, Muh. Bagus Budianto \\ Jurusan Teknik Sipil, Fakultas Teknik, Universitas Mataram \\ *corresponding author, email: h.saidah@unram.ac.id
}

Manuscript received: 29-04-2020. Accepted: 14-06-2020

\begin{abstract}
ABSTRAK
Penentuan dimensi saluran irigasi sangat ditentukan oleh besarnya nilai consumptive use yang secara empiris ditentukan oleh nilai evapotranspirasi potensial (ETo). Karena terbatasnya data pengukuran lysimeter maka nilai ETo biasa didekati dengan metode empirik dengan input data cuaca. Metode standar yang telah diakui keandalannya dan dapat digunakan secara universal adalah metode FAO Penman-Monteith. Namun penggunaan metode ini hanya memungkinkan jika tersedia data cuaca yang lengkap. Penelitian ini memodifikasi metode perhitungan ETo yang memiliki model cukup sederhana yaitu Thornthwaite dan metode Evaporasi Panci untuk mendapatkan nilai ETo yang mampu mendekati hasil metode FAO PM. Kalibrasi dilakukan dengan mencari angka koreksi dari kedua metode hingga diperoleh hasil terbaik dari kedua metode yang diukur dari angka korelasi dan nilai indeks efisiensi. Hasil yang diperoleh adalah dalam kondisi data cuaca yang terbatas metode Thornthwaite baik sebelum maupun setelah dikalibrasi memiliki akurasi yang lebih baik dari metode Evaporasi Panci. Sedangkan kalibrasi yang dilakukan berhasil meningkatkan angka korelasi dan efisiensi kedua metode secara signifikan. Namun dari kedua metode yang dikalibrasi, metode Thornthwaite memberi kinerja yang lebih baik dan memuaskan dengan angka korelasi antara 0.86 hingga 0.89 dan indeks efisiensi mencapai 0.78 .
\end{abstract}

Kata kunci: Angka koreksi; Evapotranspirasi Potensial; FAO Penman-Monteith

\begin{abstract}
Determination of irrigation channel dimensions is determined by the number of consumptive use values that are empirically determined by the potential evapotranspiration value (ETo). Due to the limited lysimeter measurement data, the ETo value is usually approached by an empirical method using weather data input. The recognized standard method for its reliability and can be used universally in determining ETo values is the FAO Penman-Monteith method. However, the use of this method is only possible if complete weather data is available. This study modified the simplest ETo calculation method, the Thornthwaite method and the evaporation pan method to obtain ETo values as accurate as FAO PM
\end{abstract}


resulted. Callibrations are made by finding the correction number to get the best results shown by the high of correlation number and the efficiency index value. The results obtained are for the area with limited weather data condition, the Thornthwaite method both before and after calibration has better accuracy than the evaporation pan method. While the calibration carried out successfully increased the correlation number and efficiency index of both methods significantly. The results of the two calibrated methods, the Thornthwaite method provides better and satisfactory performance with a ratio between 0.86 and 0.89 and the efficiency index reaches 0.78 .

Keyword: correction number; FAO-penman monteith; potential evapotranspiration

\section{PENDAHULUAN}

Evapotranspirasi potensial adalah parameter agrometeorologis yang penting untuk studi hidrologis dan klimatologis, serta untuk perencanaan dan manajemen irigasi (Sentelhas et al, 2010). Evapotranspirasi merupakan gabungan antara penguapan yang terjadi di permukaan lahan (evaporasi) dan pada permukaan tanaman pada lahan tersebut (transpirasi) (Triatmodjo, 2008). Oleh karena itu, perlu diketahui besarnya evapotranspirasi yang nantinya akan menentukan besarnya kebutuhan air di suatu daerah irigasi.

Pada kondisi sesungguhnya sangat sulit untuk membedakan antara evaporasi dan transpirasi jika tanahnya tertutup oleh tanaman. Besarnya nilai evapotranspirasi secara langsung bisa diketahui menggunakan alat ukur seperti Evapotranspirometer dan Lysimeter. Namun, untuk mengetahui nilai evapotranspirasi secara langsung dengan menggunakan alat tersebut sangatlah sulit didapatkan khususnya di Pulau Lombok karena kendala ketiadaan alat pengukuran evapotranspirasi.

Terdapat beberapa metode dalam memperkirakan besarnya evapotranspirasi yang satu sama lain memiliki kinerja yang sangat beragam jika diaplikasikan pada suatu daerah, diantaranya adalah metode Thornthwaite, Evaporasi Panci, FAO 24 Radiasi, FAO 24 Blaney Criddle, FAO 24-Penman, dan Metode FAO Penman-Monteith (FAO PM) dan lain-lain. Diantara metode tersebut Metode FAO Penman-Monteith telah digunakan sebagai standar universal dalam memperkirakan nilai evapotranspirasi potensial (ETo) (Chiew et.al., 1995; Sentelhas et al, 2010) dan sebagai standar untuk menverifikasi metode empiris lainnya dalam beberapa dekade terakhir (Chen et al., 2005).

Dalam penyelesaian perhitungan estimasi nilai ETo, berbagai metode yang telah dipublikasi luas memiliki kebutuhan data yang berbeda-beda. Metode Blaney Criddle dan Thornthwaite hanya membutuhkan data suhu udara, metode radiasi membutuhkan data suhu udara dan radiasi matahari gelombang pendek. Metode Hargreaves membutuhkan data suhu, kelembaban udara dan kecepatan angin (Hargreaves et al., 2003; Popova et al., 2006), sedangkan metode Penman dan Penman-Monteith membutuhkan input data paling banyak diantaranya adalah suhu udara, kelembaban relatif, kecepatan angin, dan radiasi matahari (Sentelhas et al., 2010).

Metode FAO Penman-Monteith (FAO PM) dianggap sebagai metode yang paling andal dan digunakan sebagai standar dan direkomendasikan untuk digunakan secara universal dalam perhitungan nilai ETo. Namun pemakaian metode ini hanya dimungkinkan jika tersedia dataset cuaca yang lengkap di lokasi studi. Maka untuk daerah yang memiliki keterbatasan alat ukur cuaca metode ini tidak akan dapat digunakan. 
Penelitian ini bertujuan untuk mendapatkan angka penyesuaian bagi metode Thornthwaite dan metode Evaporasi Panci dengan tujuan untuk memperoleh hasil perhitungan ETo yang akurat seakurat nilai standar acuan yaitu metode FAO Penman-Monteith (FAO PM) namun dengan teknik perhitungan yang mudah dan tidak membutuhkan data cuaca yang banyak. Analisis dilakukan dengan cara melakukan kalibrasi untuk kedua metode sehingga diperoleh angka koreksi bagi kedua metode dalam memperhitungkan nilai ETo yang mendekati hasil perhitungan model FAO Penman Monteith.

\section{BAHAN DAN METODE}

Pengkajian untuk mencari angka koreksi untuk perhitungan ETo ini berdasarkan pada penelitian yang dilakukan oleh Hadiswara (2015) di pulau Lombok yang melakukan pembandingan terhadap beberapa metode perhitungan nilai ETo menggunakan metode Penman original, Penman FAO Modified, Penman-Monteith, Thornthwaite dan dibandingkan terhadap evaporasi hasil pengukuran panci.

Penelitian dilakukan pada dua daerah dengan karakteristik cuaca yang berbeda, yaitu wilayah dengan iklim basah dan iklim kering. Dari sebaran dan data iklim dari Balai Penelitian Agroklimat dan Hidrologi (Balitklimat, 2003) dalam Mulyani et al., (2014) tipe iklim di Indonesia dikelompokan menjadi iklim basah (curah hujan $>2000 \mathrm{~mm} / \mathrm{tahun}$ dan iklim kering (curah hujan < $2000 \mathrm{~mm} /$ tahun. Pada lokasi penelitian, pos klimat Kopang mewakili daerah beriklim basah (curah hujan tahunan rerata $2022 \mathrm{~mm}$ ) dan Pos Klimat Keruak mewakili daerah beriklim kering (curah hujan tahunan rerata sebesar $945 \mathrm{~mm}$ ).

Penelitian melibatkan empat metode empirik yaitu Penman, Penman modifikasi FAO, FAO Penman-Monteith, dan metode Thornthwaite. Sedangkan sebagai nilai acuan digunakan hasil pendekatan ETo menggunakan metode evaporasi panci. Dimana disimpulkan metode Penman modifikasi FAO adalah metode yang paling baik karena nilainya paling mendekati dengan metode Evaporasi Panci (Hadiswara, 2015).

Penelitian lanjutan ini melakukan perubahan pada nilai standar acuan yaitu menggunakan metode FAO Penman-Monteith yang telah digunakan sebagai nilai ETo standar acuan yang direkomendasikan oleh FAO dan diyakini memiliki hasil pendekatan ETo yang paling andal dan paling mendekati nilai evapotranspirasi aktual hasil pengukuran lysimeter. Metode FAO Penman-Monteith menurunkan persamaan umumnya sebagai berikut (Allen et al., 1998).

$$
E T_{0}=\frac{0.408\left(R_{n}-G\right)+\gamma \frac{900}{T+273} u_{2}\left(e_{S}-e_{a}\right)}{\Delta+\gamma\left(1+0.34 u_{2}\right)}
$$

Dimana : $E T_{0}=$ evapotranspirasi acuan $(\mathrm{mm} / \mathrm{hari}) ; R_{n}=$ radiasi netto pada permukaan tanaman (MJ/m2/hari); $\mathrm{G}=$ Kerapatan panas terus menerus pada tanah $(\mathrm{MJ} / \mathrm{m} 2 / \mathrm{hari}) ; \mathrm{T}=$ temperatur harian rata-rata pada ketinggian $2 \mathrm{~m}(\mathrm{oC}) ; u_{2}=$ Kecepatan angin pada ketinggian 2 $\mathrm{m}(\mathrm{m} / \mathrm{s}) ; e_{s}=$ Tekanan uap jenuh $(\mathrm{kPa}) ; e_{a}=$ Tekanan uap aktual $(\mathrm{kPa}) ; e_{s}-e_{a}=$ Defisit tekanan uap jenuh $(\mathrm{kPa}) ; \Delta=$ Kurva kemiringan tekanan uap $(\mathrm{kPa} / \mathrm{oC}) ; \gamma=$ Konstanta psychrometric $(\mathrm{kPa} / \mathrm{oC})$. 
Modifikasi metode Thornthwaite dan Evaporasi Panci dilakukan dengan pertimbangan kedua metode tersebut sangat sederhana dalam pengoperasian dan hanya membutuhkan satu jenis data cuaca. Metode Thornthwaite hanya membutuhkan data suhu udara dan metode Evaporasi Panci membutuhkan data evaporasi hasil pengukuran panci. Kedua data tersebut adalah data yang relatif mudah didapatkan, khususnya data suhu udara. Sehingga diharapkan dapat menjadi solusi untuk perhitungan ETo di daerah yang memiliki pencatatan data cuaca terbatas.

Perkiraan evapotranspirasi dengan data Evaporasi Panci diperoleh dengan cara mengalikan koefisien panci terhadap hasil pengukuran evaporasi panci (Asdak, 1995). Nilai koefisien panci di daerah studi diperoleh dari hasil kalibrasi panci jenis Pan A yang dilakukan oleh instansi terkait. Nilai koefien panci di wilayah NTB bervariasi setiap bulan dengan nilai 0,91 -1,09 untuk daerah Kopang dan 0,79-0,86 untuk daerah Keruak.

Nilai evapotranspirasi potensial metode Thornthwaite didekati dengan terlebih dahulu mendapatkan indeks panas tahunan (J) berdasarkan data suhu udara bulanan rata-rata (tn) dan indeks panas rata-rata bulanan $(\mathrm{j})$.

$$
\begin{gathered}
j=\left(\frac{t n}{5}\right)^{1,514} \\
J=\sum_{1}^{12} j
\end{gathered}
$$

Sedangkan besaran evapotranspirasi potensialnya diperoleh dengan persamaan:

$$
\begin{aligned}
& E p^{*}=1,6\left(\frac{10 t}{J}\right)^{a} \text { dan } \\
& a=675 \times 10^{-9} J^{3}-771 \times 10^{-7} J^{2}+178 \times 10^{-4} J+0.498
\end{aligned}
$$

dimana jumlah hari diasumsikan 30 dan jumlah jam siang perhari adalah 12 jam. Dan jika bukan 12 jam perhari maka menggunakan persamaan (Soemarto, 1986) :

$$
E p=E p^{*}\left(\frac{S \times T x}{30 \times 12}\right)
$$

Dimana $\mathrm{S}$ adalah jumlah hari dalam bulanan tertentu; $\mathrm{Tx}=$ jumlah jam rata-rata sehari antara matahari terbit hingga tengglam dalam bulan tertentu.

Proses modifikasi model dilakukan dengan mencari angka koreksi menggunakan cara trial and error untuk kedua metode. Hasil yang diperoleh dari model yang telah terkalibrasi tersebut kemudian diuji kedekatannya terhadap nilai acuan yaitu nilai ETo dari model FAO Penman-Monteith, dengan mengukur angka korelasi dan indeks efisiensi model menggunakan persamaan (Sutcliffe, 1971 dalam McCuen et al., 2006):

$$
E f=1-\left[\frac{\sum_{i=1}^{n}\left(\hat{Y}_{i}-Y_{i}\right)^{2}}{\sum_{i=1}^{n}\left(Y_{i}-\bar{Y}\right)^{2}}\right]
$$

Dimana $\hat{Y}_{i}$ dan $Y_{i}$ adalah nilai estimasi dan ke-i, sedangkan $Y_{i}$ adalah rata-rata nilai observasi dengan jumlah data $\mathrm{n}$ dan $\mathrm{n}$ adalah jumlah pasangan data. 


\section{HASIL DAN PEMBAHASAN}

Penelitian dilakukan pada dua daerah dengan karakteristik iklim berbeda di Pulau Lombok yaitu Kopang yang beriklim basah dan Keruak yang beriklim kering. Pada kedua lokasi ini memiliki pencatatan data cuaca yang memadai sehingga dimungkinkan untuk melakukan perhitungan ETo metode FAO PM, juga memiliki data pengukuran evaporasi panci serta pengukuran suhu udara sehingga memungkinkan untuk pengujian metode Evaporasi Panci dan Thornthwaite serta membandingkan hasilnya terhadap metode FAO PM.

Terdapat banyak studi yang menguji pemakaian metode Thornthwaite untuk pemakaian perhitungan evapotranspirasi di seluruh dunia. Diantaranya adalah pengujian dan pembandingan metode Thornthwaite terhadap metode Penman Monteith untuk perhitungan nilai ETo harian di Hungaria (Lakatos, et.al, 2020), perbandingan metode Thornthwaite terhadap metode Penman di India (Kumar et al., 1987), perbandingan metode Thornthwaite dan data evaporasi panci terhadap metode Penman-Monteith untuk perkiraan nilai evapotranspirasi potensial di China (Chen et al., 2005), penyesuaian metode Thornthwaite untuk perhitungan angka evapotranspirasi harian di Iran (Sepaskhah dan Razzaghi, 2009), kalibrasi dan penyesuaian metode Thornthwaite untuk pemakaian di daerah semi arid dan sub humid di Mexico (Bautista et al., 2009), dan sebagainya.

Sedangkan studi tentang pemakaian data evaporasi panci menjadi data evapotranspirasi potensial dilakukan oleh Raghuwanshi dan Wallende (1998) dengan membuat persamaan baru penentuan koefisien panci menggunakan data cuaca. Grismer et al., (2002) membuat prosedur perhitungan untuk mengubah angka evaporasi menjadi evapotranspirasi dalam bentuk persamaan koefisen panci dan menghasilkan nilai ETo yang keakuratannya menyamai metode FAO 24 atau dikenal dengan metode Radiasi. Sumner dan Jacobs (2005) membandingkan Persamaan FAO PM, Priestley-Taylor, evapotranspirasi referensi dan evaporasi panci terhadap angka evapotranspirasi aktual di sebuah padang rumput di USA.
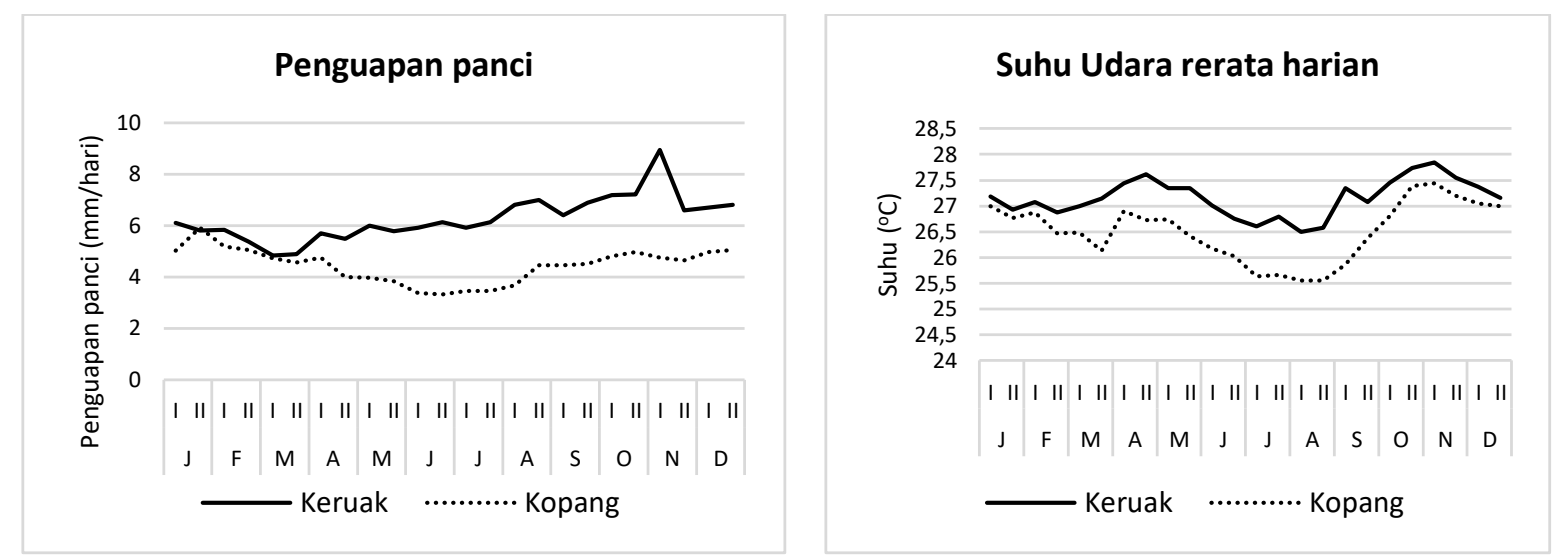

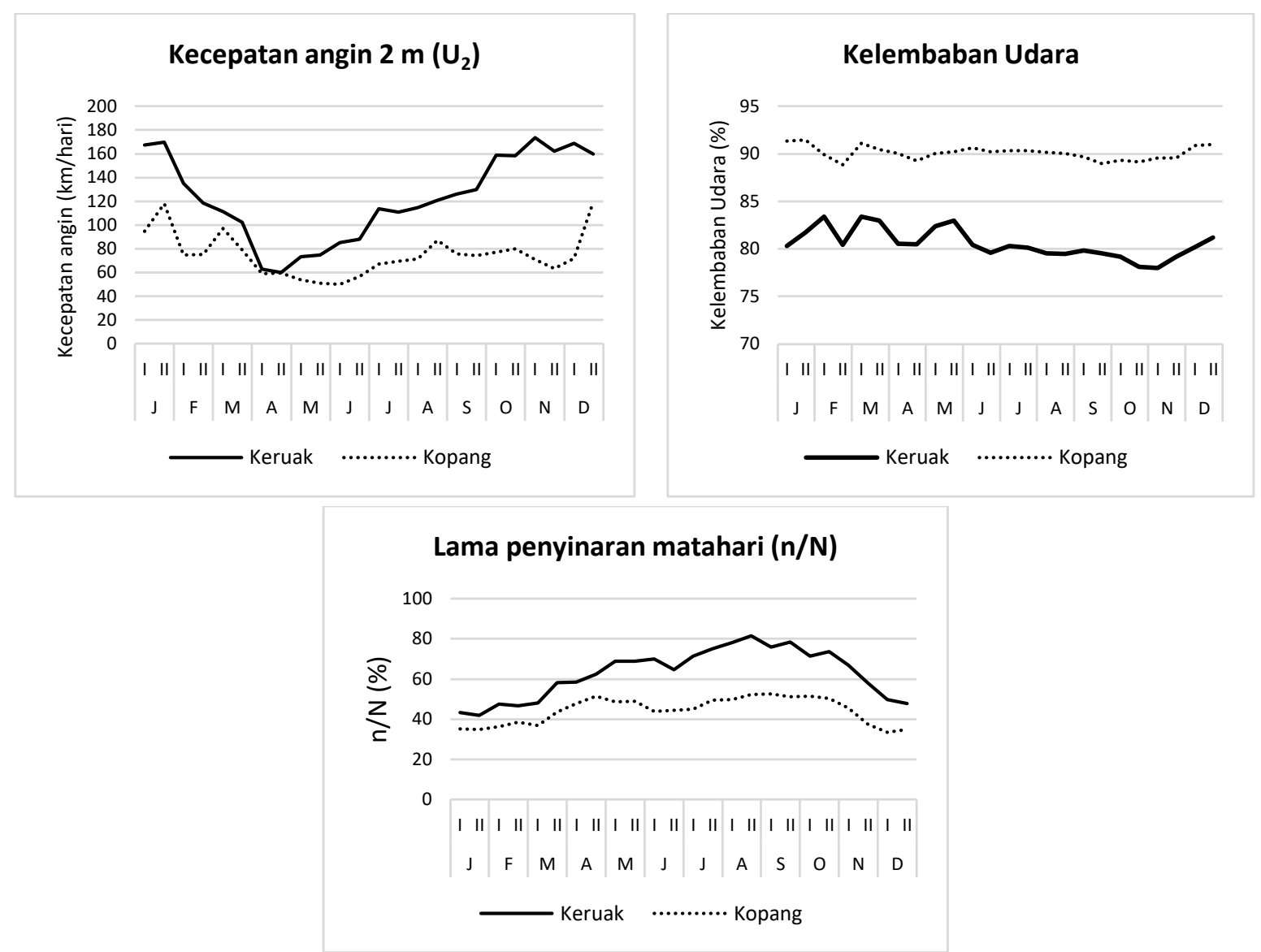

Gambar 1. Data cuaca rerata harian yang disajikan dalam setengah bulanan di lokasi studi Pos iklim Keruak (elv. +87.17) dan pos iklim Kopang (elv. +384.96 dengan lama pengamatan 35 tahun dari 1981-2015

Penelitian ini berlokasi di wilayah Nusa Tenggara Barat khususnya Pulau Lombok, menggunakan data parameter cuaca yang dikumpulkan dari Pos Iklim Kopang yang berada di Kabupaten Lombok tengah dan Pos Iklim Keruak di kabupaten Lombok Timur, sebagaimana disajikan pada gambar 1 .

\section{Metode Thornthwaite}

Perhitungan ETo dengan metode Thornthwaite membutuhkan input data suhu udara rerata bulanan pada kedua lokasi. Kopang adalah daerah yang beriklim basah dengan curah hujan rerata tahunan sebesar $2052 \mathrm{~mm}$. Pos iklim Kopang terletak pada elevasi +384,96 m lebih tinggi dari elevasi rerata daerah Kopang yaitu $+355 \mathrm{~m}$. Suhu udara yang tercatat bervariasi antara musim kemarau dan penghujan yang berkisar antara $25,55{ }^{\circ} \mathrm{C}$ sampai $27,44{ }^{\circ} \mathrm{C}$. Sedangkan daerah Keruak tergolong daerah kering yang ditandai dengan curah hujan $<2000$ $\mathrm{mm} /$ tahun yaitu sebesar 968,41mm/tahun. Pos iklim Keruak terletak pada elevasi +87.17 , lebih tinggi dari elevasi rerata daerah Keruak yaitu $+67.78 \mathrm{~m}$. Suhu rerata harian berkisar antara 26,5 ${ }^{\circ} \mathrm{C}$ sampai $27,85^{\circ} \mathrm{C}$, terendah terjadi pada bulan Agustus dan tertinggi bulan November. Hasil perhitungan niai ETo menggunakan metode Thornthwaite untuk wilayah Kopang dan Keruak disajikan pada gambar 2 . 


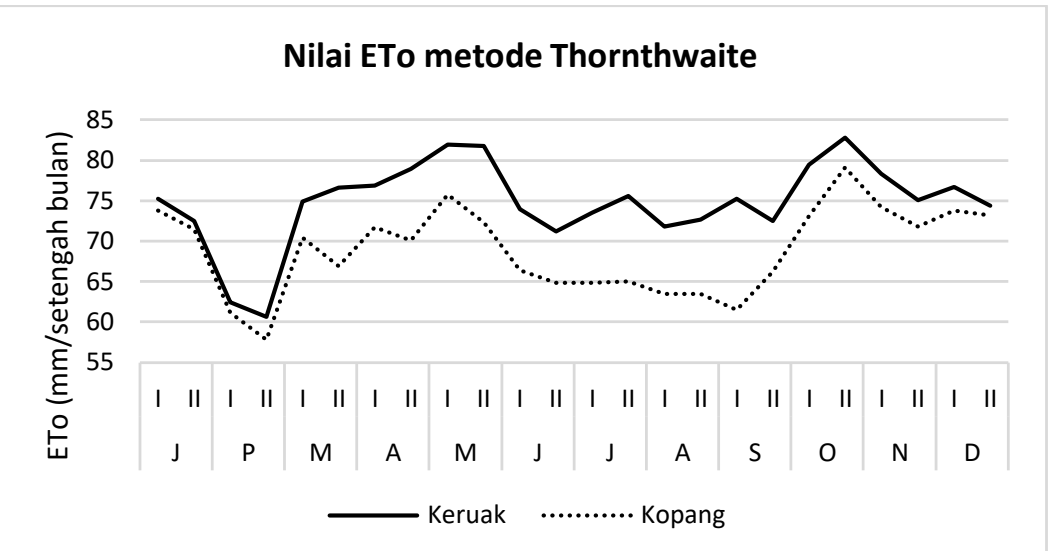

Gambar 2. Nilai ETo setengah bulanan dengan metode Thornthwaite dengan input data pengukuran suhu udara di pos iklim Keruak dan Kopang di Lombok, Nusa Tenggara Barat

Berdasarkan hasil yang diperoleh dapat dilihat estimasi nilai ETo untuk wilayah Keruak adalah secara konsisten lebih tinggi dari ETo wilayah Kopang. Hal ini disebabkan karena Keruak adalah daerah pesisir dengan elevasi rata-rata $+67.78 \mathrm{~m}$ di atas permukaan laut, yang lebih rendah dibandingkan elevasi rata-rata daerah Kopang yaitu $+355 \mathrm{~m}$. Hal ini membuat suhu udara sepanjang tahun di wilayah Keruak menjadi lebih tinggi dari wilayah Kopang.

Mengingat suhu wilayah Keruak yang lebih tinggi dari Kopang, maka nilai ETo yang dihasilkan metode ini pun hampir sepanjang tahun secara konsisten lebih tinggi dari pada Kopang. Dilihat dari Gambar 2, nilai ETo di kedua lokasi menunjukkan karakteristik yang sama yaitu mengalami titik terendah pada bulan Februari dan tertinggi pada bulan Oktober.

\section{Evaporasi Panci}

Nilai ETo bisa diestimasi menggunakan data penguapan dari Evaporasi Panci, dengan cara mengalikannya dengan angka koefisien panci. Untuk daerah tropis seperti Indonesia dengan kecepatan angin lemah sampai sedang dan kelembaban udara rata-rata di atas $70 \%$, harga koefisien panci untuk mengetahui besarnya ETo hanya berkisar antara 0,65 - 0,85 (Harto, 1993). Namun menurut Balai Informasi Sumber Daya Air Nusa Tenggara Barat (BISDA NTB), nilai koefisien panci penguapan kelas A yang dimiliki pos iklim Kopang dalam menentukan evapotranspirasi potensial rujukan, berkisar antara 0,91-1,10. Perbedaan koefisien dengan standar FAO ini disebabkan oleh beberapa faktor, diantaranya ialah adanya lumut yang tumbuh di dalam panci, pengecatan dinding dan dasar panci berkala tahunan yang tidak tepat waktu sehingga terjadi karat di dalam panci, serta air yang digunakan untuk mengisi panci belum tentu air yang jernih (BISDA NTB, 2014). Koefisien panci bulanan untuk kedua pos iklim ini disajikan dalam Gambar 3. 


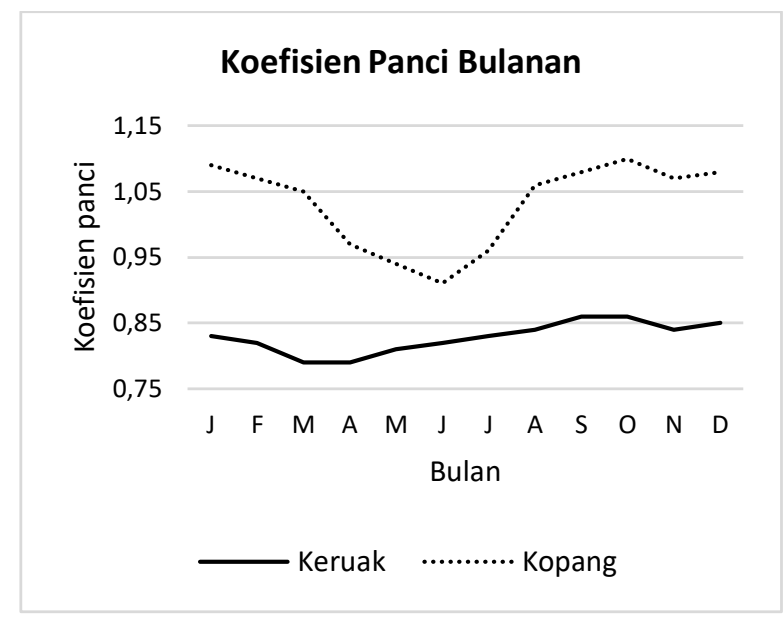

Gambar 3. Koefisien panci penguapan bulanan untuk pos iklim Keruak dan Kopang, Nusa Tenggara Barat

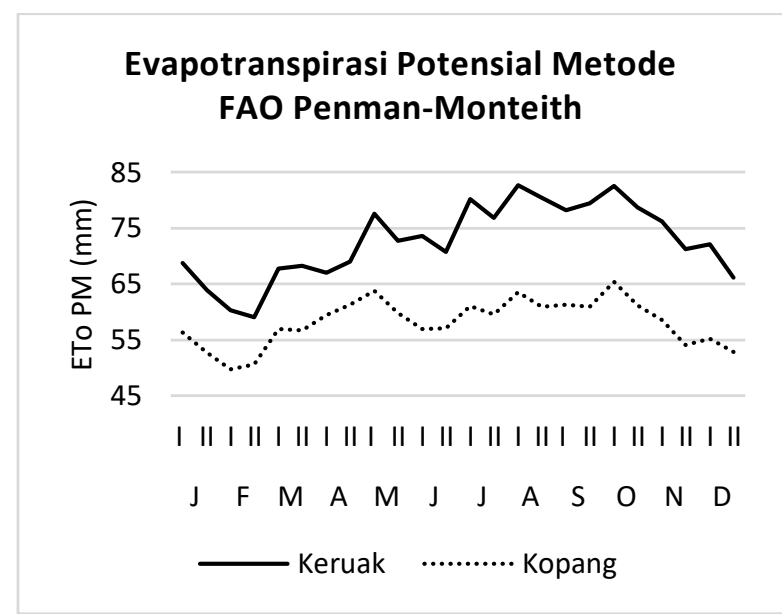

Gambar 4. Hasil perhitungan nilai ETo menggunakan metode FAO Penman-Monteith

Estimasi nilai ETo dari data penguapan panci menggunakan data pengukuran penguapan dalam 35 tahun sejak 1981-2015 yang nilai reratanya dapat dilihat pada Gambar 1 dan nilai ETo hasil pendekatan metode ini disajikan pada Gambar 4.

Hasil pendekatan panci penguapan dalam memperkirakan nilai ETo menunjukkan hasil estimasi nilai ETo yang cenderung tidak konsisten dalam menggambarkan keadaan cuaca daerah yang diwakilinya. Pada daerah Kopang dimana pada awal tahun sepanjang bulan Januari sampai tengah bulan pertama April, memiliki nilai ETo yang lebih tinggi dari Keruak dan setelah itu nilai ETo di Kopang selalu lebih rendah. Padahal hasil pengukuran penguapan dari panci mecatat bahwa hampir sepanjang tahun penguapan di Keruak lebih tinggi dari Kopang. Ketidak-konsistenan nilai ETo terhadap nilai evaporasi pengukuran panci tersebut diakibatkan oleh besaran angka koreksi panci yang digunakan untuk pos iklim Kopang yang melebihi standar dari FAO.

\section{FAO Penman-Monteith}

Berdasarkan FAO-1992 (Smith et. al., 1992), metode FAO Penman-Monteith adalah metode yang secara konsisten memperlihatkan hasil yang lebih baik dari metode-metode lain dalam memperhitungkan ETo menggunakan acuan data lysimeter. Oleh karena itu metode FAO Penman-Monteith ini digunakan sebagai nilai ETo standar acuan yang direkomendasikan oleh FAO (Allen, 1998).

Metode FAO Penman-Monteith dalam penelitian ini digunakan sebagai nilai acuan nilai ETo rujukan dan digunakan untuk mengkalibrasi ETo yang dihasilkan oleh metode Thornthwaite dan metode Evaporasi Panci. Penelitian tentang pencarian angka koreksi bagi beberapa metode yang salah satunya adalah metode Evaporasi Panci dengan jenis pan A juga pernah dilaksanakan di Australia oleh Chiew et.al (1995).

Perhitungan ETo dengan metode FAO Penman-Monteith membutuhkan input data cuaca diantaranya adalah data suhu udara, kecepatan angin pada ketinggian $2 \mathrm{~m}$ di atas permukaan, kelembaban udara, dan penyinaran matahari. Perhitungannya dilakukan dengan persamaan 1. 
Gambar 4 menyajikan hasil perhitungan nilai ETo untuk daerah Keruak dan Kopang menggunakan metode FAO Penman-Monteith.

Hasil perhitungan menggunakan metode FAO Penman-Monteith ini menghasilkan angka ETo yang konsisten lebih tinggi untuk daerah Keruak jika dibandingkan dengan Kopang, baik pada musim penghujan maupun kemarau. Kedua lokasi juga memiliki kesamaan pada trend dan kecenderungan nilai ETo di sepanjang tahun, dimana angka terendah terjadi pada bulan Februari dan tertinggi terjadi pada bulan Oktober. Kecenderungan yang senada juga diperlihatkan oleh hasil perhitungan metode Thornthwaite. Hal ini menjadi petunjuk awal bahwa metode Thornthwaite memiliki kedekatan dalam karakteristisasi nilai evapotranspirasi potensial di wilayah penelitian, sehingga diharapkan hasil kalibrasi dapat digunakan untuk memperhitungkan nilai ETo pada daerah dengan ketersediaan data cuaca terbatas.

Untuk selanjutnya hasil perhitungan yang diperoleh dari metode FAO Penman-Monteith ini akan digunakan sebagai angka acuan untuk proses kalibrasi metode Thornthwaite dan Metode Evaporasi Panci.

\section{Kalibrasi}

Proses kalibrasi dilakukan trial and error hingga diperoleh angka koreksi yang menghasilkan nilai efisiensi tertinggi yang diperoleh dari persamaan 7. Pendekatan dilakukan dengan sebelumnya membaca kecenderungan nilai rasio yang dihasilkan kedua metode. Nilai rasio tersebut kemudian dikelompokkan berdasarkan nilai-nilai yang besarnya berdekatan. Kemudian hasil kedua metode yang masih asli dikalibrasi dengan cara mengalikannya dengan angka koreksi tersebut. Perolehan angka koreksi disajikan pada tabel 1.

Tabel 1. Nilai angka koreksi

\begin{tabular}{lllc}
\hline Lokasi & Metode & Bulan & Angka koreksi \\
\hline Keruak & Thornthwaite & Juni - Oktober & 1.06 \\
& & November - Mei & 0.92 \\
\cline { 2 - 4 } & Evaporasi Panci & Februari - Agustus & 1.01 \\
& & September - Januari & 0.83 \\
\hline Kopang & Thornthwaite & Februari - Juni & 0.85 \\
(Elv. +355) & & Juli - September & 0.95 \\
& & Oktober - Januari & 0.76 \\
\cline { 2 - 4 } & Evaporasi Panci & April - Juli & 1.12 \\
& & Agustus - Maret & 0.72 \\
\hline
\end{tabular}

Terjadi peningkatan yang signifikan baik nilai efisiensi model maupun angka korelasi antara hasil perhitungan ETo dengan metode Thornthwaite dan Evaporasi Panci sebelum dan setelah dilakukan kalibrasi, dimana nilai ETo dari metode FAO Penman-Monteith digunakan sebagai nilai acuan, dan hasilnya disajikan pada tabel 2 serta gambar 6 dan 7 
Tabel 2. Nilai efisiensi Metode Thonthwaite dan Evaporasi Panci sebelum dan setelah dikalibrasi

\begin{tabular}{llcrrr}
\hline \multirow{2}{*}{ Lokasi } & \multirow{2}{*}{ Metode } & \multicolumn{2}{c}{ Angka korelasi } & \multicolumn{2}{c}{ Nilai efisiensi } \\
\cline { 3 - 6 } & & sebelum & setelah & sebelum & efisiensi \\
\hline Keruak & Thornthwaite & 0.50 & 0.86 & 0.09 & 0.70 \\
(Elv. +67.78) & Evaporasi Panci & 0.64 & 0.84 & -2.17 & 0.26 \\
\hline Kopang & Thornthwaite & 0.21 & 0.89 & -8.10 & 0.78 \\
(Elv. +355) & Evaporasi Panci & -0.35 & 0.24 & -22.34 & -1.57 \\
\hline
\end{tabular}

Pemakaian metode evaporasi panci memperlihatkan kinerja yang lebih rendah dibandingkan metode Thornthwaite dalam memperkirakan nilai ETo yang ditunjukkan oleh rendahnya angka korelasi dan nilai efisiensi terhadap nilai FAO Penman-Monteith sebagai standart acuan. Nilai efisiensi yang rendah menunjukkan kinerja yang rendah dari metode tersebut. Pemakaian metode evaporasi panci di lokasi penelitian memberikan nilai efisiensi yang sangat rendah (negatif) di kedua lokasi, terutama daerah Kopang yang memiliki nilai efisiensi yang jauh lebih rendah dibandingkan Keruak, yaitu -22,34 sementara Keruak sebesar $-2,17$. Bahkan dari angka korelasi negatif yang dihasilkan memberi gambaran adanya keanehan dalam data penguapan di lokasi ini. Angka korelasi negatif dalam hal ini dapat diartikan bahwa penguapan air dalam panci cenderung berkebalikan arah dengan nilai evapotranspirasi potensial acuan. Hal ini menjadi sulit diterima karena pada dasarnya evaporasi dan evapotranspirasi adalah aktivitas yang sama, yaitu penguapan.

Hal ini sangat mungkin disebabkan oleh tingginya angka koefisien panci yang disarankan pihak pengelola yang melebihi standar yang ditetapkan oleh FAO. Angka koefisien panci dalam perolehannya dipengaruhi oleh salah satunya adalah faktor perawatan panci, yang mana pada panci jenis Pan A yang digunakan di Kopang ditemukan adanya lumut yang tumbuh di dalam panci. Selain itu pemakaian air yang belum tentu jernih dan pengecatan dinding dan dasar panci yang kurang tepat juga menjadi catatan dalam mempengaruhi tingginya angka koefisien panci ini (BISDA NTB, 2014).
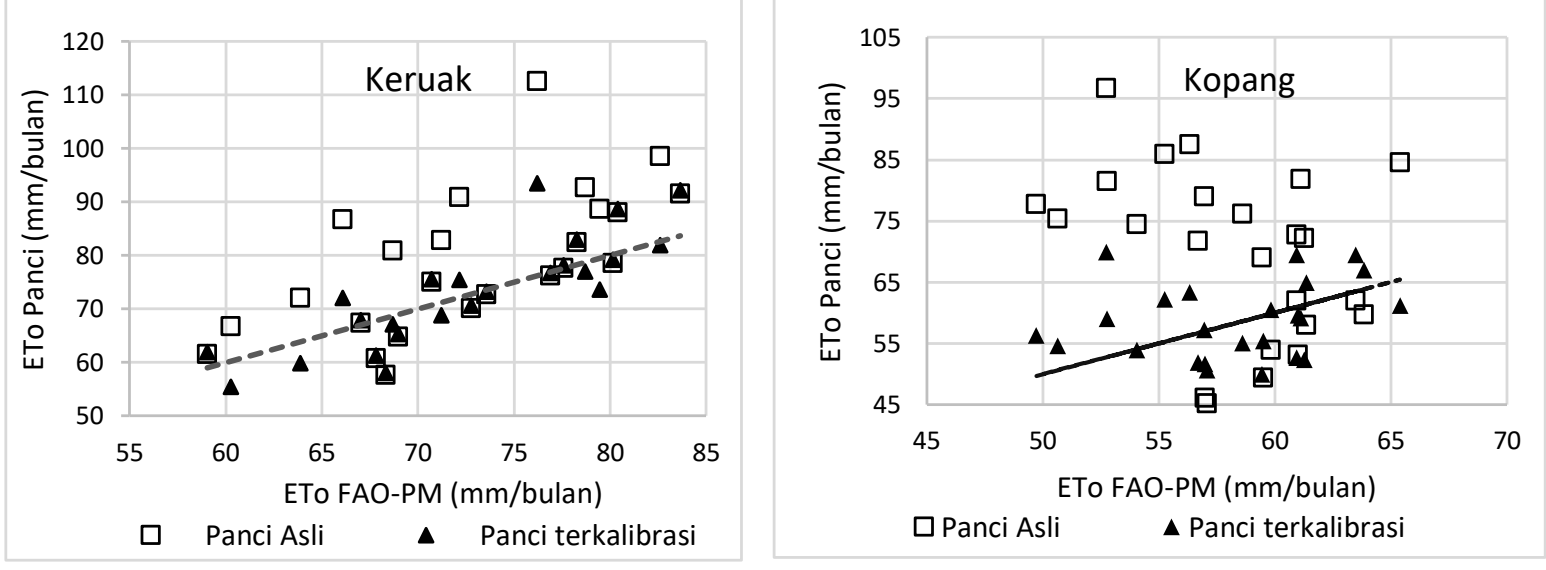

Gambar 6. Grafik sebaran nilai ETo bulanan dengan metode Evaporasi Panci sebelum dan setelah kalibrasi 

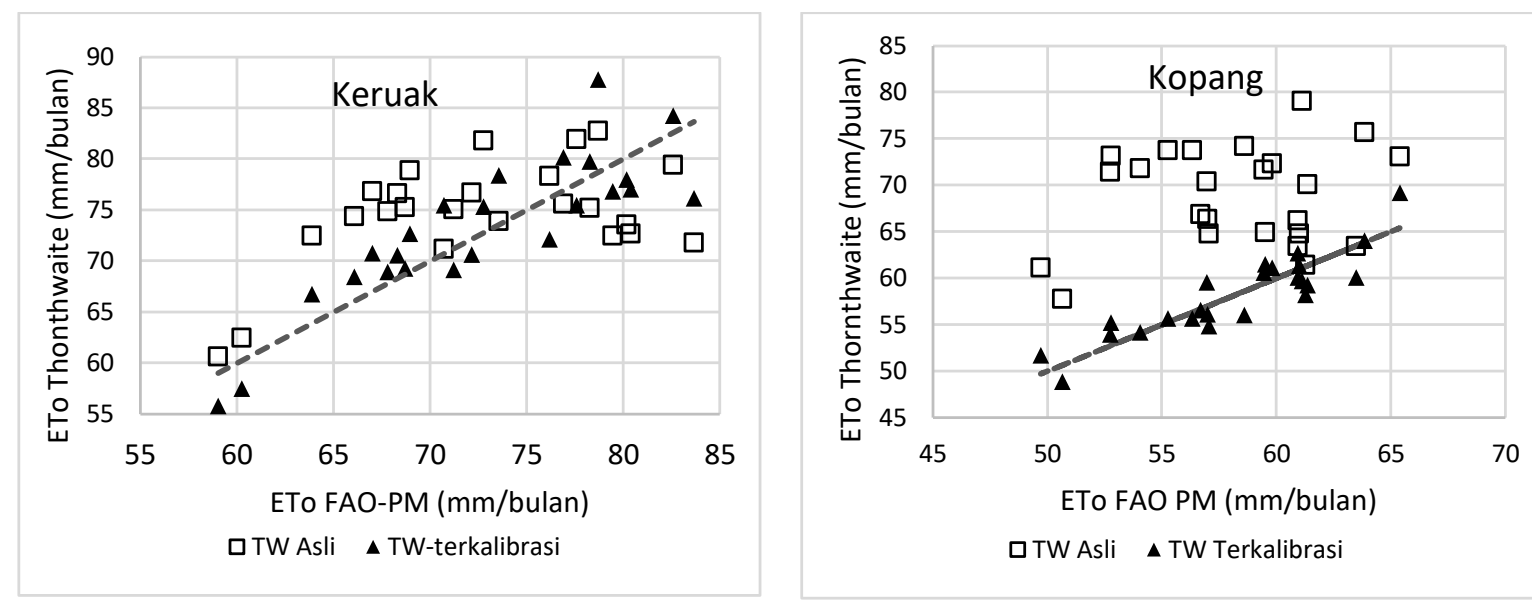

Gambar 7. Grafik sebaran nilai ETo bulanan dengan metode Thornthwaite sebelum dan setelah kalibrasi

Berdasarkan parameter nilai uji statistik pada Tabel 2 dan Gambar 6-7 diperoleh gambaran bahwa kinerja dari metode Evaporasi Panci dan metode Thornthwaite sama-sama rendah untuk penggunaan persamaan aslinya. Namun dapat dikatakan metode Thornthwaite memiliki kinerja yang lebih baik jika dibandingkan dengan metode Evaporasi Panci jika dilihat dari nilai efisiensi modelnya.

Kalibrasi yang dilakukan dengan mengalikan angka koreksi terhadap hasil perhitungan persamaan Thornthwaite dan Evaporasi Panci telah secara signifikan meningkatkan kinerja kedua metode pada kedua lokasi penelitian. Dari kedua metode ternyata Thornthwaite memiliki hasil akhir yang jauh lebih baik dalam memprediksi nilai ETo dibandingkan metode Evaporasi Panci dengan nilai efisiensi lebih dari 0,7 yang masuk dalam kategori memuaskan, dan angka korelasi terhadap nilai ETo FAO-PM lebih dari 0,85. Sehingga dapat disimpulkan metode Thornthwaite lebih baik dan disarankan pemakaiannya disertai penggunaan angka koreksi untuk daerah yang memiliki keterbatasan data pengukuran cuaca. Selain itu metode Thornthwaite dalam versi aslinya hanya memerlukan data suhu udara dalam perhitungannya, dimana data suhu termasuk jenis data yang sangat umum dan mudah ditemui di lokasi dengan kondisi data terbatas sekalipun. Selain itu model Thornthwaite juga sangat sederhana dan mudah dalam pengoperasian.

\section{KESIMPULAN}

Pemakaian metode Thornthwaite dan metode Evaporasi Panci dapat digunakan untuk memprediksi nilai evapotranspirasi potensial di daerah yang beriklim kering maupun basah dengan akurasi bervariasi. Namun baik dalam kondisi asli maupun terkalibrasi, metode Thornthwaite lebih dianjurkan pemakaiannya dibandingkan metode Evaporasi Panci untuk perhitungan nilai ETo pada daerah dengan data cuaca terbatas.

\section{Ucapan Terima Kasih}

Peneliti mengucapkan terima kasih kepada Universitas Mataram tempat peneliti bekerja dan mengabdi, juga kepada Eko Priadhi Hadiswara untuk data-datanya. 


\section{DAFTAR PUSTAKA}

Allen, G.R., L.S. Pereira, D. Raes, M. Smith, 1998. Crop Evapotranspiration - Guidelines for computing crop water requirements - FAO Irrigation and drainage paper 56, FAO Food and Agriculture Organization of the United Nations, Rome.

Asdak, Chay. 1995. Hidrologi Dan Pengelolaan Daerah Aliran Sungai. Yogyakarta: Gajah Mada University Press.

Bautista, F., D. Bautista, C. Delgado, 2009. Calibration of The Equations of Hargreaves And Thornthwaite To Estimate the Potential Evapotranspiration in Semi-Arid and Subhumid Tropical Climates for Regional Applications, Atmósfera, vol.22, no.4, México.

BISDA NTB, 2014. Koefisien Evaporasi Panci A Dalam Menentukan Evapotranspirasi Rujukan Pada 5 Pos Klimatologi Di Pulau Lombok, Booklet Informasi Sumber Daya Air. Vol. 2. No. 1

Chiew, F.H.S., N.N. Kamaladasa, H.M. Malano, T.A. McMahon, 1995. Penman-Monteith, FAO-24 Reference Crop Evapotranspiration and Class-A Pan Data in Australia, Agricultural Water Management 28, 9-21

Chen, D., G. Gao, C.Y. Xu, J. Guo, R. Ren, 2005, Comparison of The Thornthwaite Method and Pan Data with The Standard Penman-Monteith Estimates of Reference Evapotranspiration in China, Climate Research, Vol. 28: 123-132

Grismer, M.E., M. Orang, R. Snyder, R. Matyac, 2002. Pan Evaporation to Reference Evapotranspiration Conversion Methods, J. Irrig. Drain Eng., 28:180-184.

Hadiswara, E.P. 2015. Analisis Perbandingan Beberapa Metode Evapotranspirasi Pada Daerah Karakteristik Basah Dan Karakteristik Kering di Pulau Lombok, Skripsi, Universitas Mataram

Hargreaves, G.H., F. ASCE, R.G. Allen, 2003. History and Evaluation of Hargreaves Evapotranspiration Equation, J. Irrig. Drain Eng., 129:53-63

Harto, Sri. 1993. Analisis Hidrologi. Jakarta: Gramedia Pustaka Utama.

Kumar, K.K., K.R. Kumar, and P.R. Rakhecha, 1987. Comparison of Penman and Thornthwaite Methods of Estimating Potential Evapotranspiration for Indian Conditions, Theor. Appl. Climatol. 38, 140-146

Lakatos, M., T. Weidinger, L. Hoffmann, Z. Bihari, A. Horváth, (2020). Computation of daily Penman-Monteith reference evapotranspiration in the Carpathian Region and comparison with Thornthwaite estimates, Adv. Sci. Res., 16, 251-259, 2020

Popova, Z., M. Kercheva, L.S. Pereira, 2006. Validation of The Fao Methodology for Computing Eto With Limited Data. Application to South Bulgaria, Irrig. And Drain. 55: 201-215

McCuen, R.H., Z. Knight, and A.G. Cutter, 2006. Evaluation of the Nash-Sutcliffe Efficiency Index, J. Hydrol. Eng.11:597-602

Mulyani, Anny., D. Nursyamsi, I. Las, 2014. Percepatan Pengembangan Pertanian Lahan Kering Iklim Kering di Nusa Tenggara, Balai Besar Penelitian dan Pengembangan Sumberdaya Lahan Pertanian, Bogor. 
Raghuwanshi, N.S., and W.W. Wallende, 1998. Converting from Pan Evaporation to Evapotranspiration, J. Irrig. Drain Eng. 124:275-277

Sentelhas, P.C., T.J. Gillespie. E.A. Santos, 2010. Evaluation of FAO Penman-Monteith and alternative methods for estimating reference evapotranspiration with missing data in Southern Ontario, Agricultural Water Management 97, 635-644

Sepaskhah, A.R., and F. Razzaghi, 2009. Evaluation of the adjusted Thornthwaite and Hargreaves-Samani methods for estimation of daily evapotranspiration in a semi-arid region of Iran, Archives of Agronomy and Soil Science Vol. 55, No. 1, 51-66

Smith, M., R. Allen, J.L Monteith, A. Perrier, L. Santos Pereira, and A. Segeren, 1992. Expert Consultation on Revision of FAO Methodologies for Crop Water Requirements. Food and Agriculture Organisation of the United Nations (Land and Water Development Division), Rome, 60 pp.

Soemarto, C.D. 1986. Hidrologi Teknik. Surabaya: Usaha Nasional

Sumner, D.M. and J.M. Jacobs, 2005. Utility of Penman-Monteith, Priestley-Taylor, reference evapotranspiration, and pan evaporation methods to estimate pasture evapotranspiration, Journal of Hydrology 308, 81-104

Triatmodjo, B., 2008. Hidrologi Terapan. Yogyakarta: Beta Offset. 